\title{
Let's Move It Move It: Thais' Attitude Toward English as a Lingua Franca
}

\author{
Jeffrey Dawala Wilang \\ School of Foreign Languages, Institute of Social Technology, Suranaree University of Technology, Thailand \\ Piyathat Siripol \\ Independent Researcher, Thailand
}

\begin{abstract}
Recently, a Facebook group under the name "โยกย้าย มาส่ายสะโพกโยกย้าย" (Let's move it move it) brought together Thais around the globe who share a similar goal of moving abroad. One of the most popular discussions was their concern over their English language skills and the "move-in" country of preference. Since this virtual community is an interesting context to explore, a survey questionnaire was distributed online to know their attitudes toward English as a lingua franca (ELF). To know if Thais' attitude on EFL differs based on their "move-in" country of preference, the participants were categorized based on Kachruvian three concentric circles - Inner, Outer, and Expanding as well as Any circle - a combination of two or more circle. Findings show the strongly favorable attitudes of Thais toward the following aspects - the focus on intelligibility, the use of English to communicate with both native and non-native speakers of English, learning materials for a multicultural environment, and exposure to varieties of English. Despite the favorable attit ude, the Expanding circle and Any circle groups strongly agreed that Standard British or American English should be taught. All circles disagreed that "any linguistic use that does not conform to Standard English is incorrect." Discussions of results were provided in the study.
\end{abstract}

Index Terms—Attitude, English as a lingua franca, Facebook, Moving abroad, English language

\section{INTRODUCTION}

The Facebook group under the name "ย้ายประเทศกันเถอะ” (Let's move abroad) which later changed its name to "โยกย้าย มาส่ายสะโพกโยกย้าย" (Let's move it move it) created sensational discussions and ways to migrate out of Thailand as a result of what they broadly mentioned, "a hopeless future in Thailand." Topics of discussion vary from social security benefits, medical service, educational and job opportunities, travel documents to everyday living experiences. One of the topics with significant importance was that of English language learning and use. Many discussions have been about methods and techniques to learn the English language, both from the experienced and the less experienced group members. Before their "move-out" from Thailand, some members appear to be very motivated to learn English for everyday communication and specific purposes. Many were concerned with their ability to use English in various communicative events abroad.

The dynamic discussion of ways to learn English reflects different beliefs and attitudes toward the status of English as global English, international language, or lingua franca. Specifically, this virtual group provides a newer context for researchers to explore topics with a more diverse group of participants from mainstream society. Accordingly, virtual communities are social aggregations that emerge online when groups of people engage in public discussions involving human emotions to form personal relationships in cyberspace (Rheigngold, 1993). Facebook, therefore, is an excellent source of data for it is one of the most popular social network sites on the web (Al-Saggaf, 2017; Dhaha \& Igale, 2014).

It is unknown how members of virtual communities view the status of the English language. For example, some who desire to go to countries that do not have English as an official language may view the status of the English language differently than those who want to go to English-speaking countries. Very few studies, if any, have attempted to explore such a virtual community on Facebook and their attitudes toward English as a lingua franca. Herein, ELF is referred to by Jenkins (2009) as a "specific communication context: English being used as a lingua franca, the common language of choice, among speakers who come from different lingua cultural backgrounds." Seidlhofer (2011) defined it as "any use of English among speakers of different first languages for whom English is the communicative medium of choice" (p. 7).

Differences in attitudes can be furthered based on their "move-in" country of preference. Using Kachruvian three concentric circles, some dream of going to the Expanding circle such as South Korea or Japan. Some prefer the Outer circle, such as Singapore or Malaysia. And many have set the goal of going to countries in Inner circle countries such as the USA, Australia, the UK, and Canada. The Any circle was added to categorized participants who do not have a specific country or circle to move in. The country of preference gives rise to insights into how English is used as a lingua franca (ELF) and how it is perceived among a group in a virtual community who may not have background 
knowledge about the school of thoughts on Englishes or ELF. Depending on their chosen destination, their attitudes toward ELF may vary as a result.

Previous research studies on attitude towards ELF focus primarily on similar contexts of participants from schools and universities (Boonsuk, Ambele, \& Buddharat, 2018; Boonsuk \& Ambele, 2021; Ploywattanawong \& Trakulkasemsuk, 2014; Phusit \& Suksiripakonchai, 2018; Snodin \& Young, 2015). Thus, the attitude toward ELF as a tool to communicate among different age groups and "move-in" country of preference with a similar goal of going abroad appears to be a gap in previous literature. In addition, a more diverse population from the mainstream society who desire to go to countries in the Inner circle, Outer circle, and Expanding circle have been little, if any, categorized and studied. Let alone, the exploration of attitudes towards ELF from virtual communities of Thais is very limited.

We argue that virtual communities on Facebook may provide an insightful reflection of attitudes as it enables freedom of expression without the need to expose the participants' identities (Krisvianti \& Triastuti, 2020). We also assume that those who prefer the Inner circle are inclined toward "native speakerism" attitudes. In contrast, those who chose Outer or Expanding circles may have more malleable attitudes on ELF. Therefore, this study aims to understand the attitudes toward ELF among Thais who want to move abroad and whether there are any differences of attitudes according to their "move-in" country of preference. Two questions are sought in the study: (1) What are the attitudes toward English as a lingua franca among Thais who want to move abroad? (2) Are there any differences in attitudes according to their "move-in" country of preference?

\section{LITERATURE REVIEW}

The role and function of the English language have been shifting due to the increasing number of non-native speakers of English worldwide, causing the rise of English as a lingua franca (ELF hereafter). Jenkins (2006) defines ELF as a "world language whose speakers communicate mainly with other non-native speakers, often from different L1s than their own" (p.140). Various aspects of ELF have been explored to gain deeper insight together with affective factors such as attitudes. In the academe, one of the reasons is because affective factors can influence outcomes of learning. Ellis (1994), for instance, mentioned "that affective factors are obviously of crucial importance in accounting for individual differences in learning outcomes. Whereas learners' beliefs about language learning are likely to be fairly stable, their affective states tend to be volatile, affecting not only overall progress but responses to particular learning activities on a day-by-day and even moment-by-moment basis" (p. 483). Outside the academe, language attitudes may predict the individual's ability to become functional in their preferred "move-in" country.

One of the factors that affect attitudes toward ELF is native-speakerism. Defined by Holliday, it is "an established belief that 'native-speaker' teachers represent a 'Western culture' from which springs the ideals both of the English language and English language teaching methodology" (Holliday, 2006). Native-speakerism is an ideology or an 'attitude of mind' that affects native and non-native speaker-teachers (Waters, 2007). Attitudes on ELF and many linguistic aspects were explored during the past years to gain insight from the perspectives of both L2 English learners and teachers. Sung (2016), for instance, conducted a qualitative inquiry by interviewing a group of students from Hong Kong university on their ELF communication experiences, particularly on their accent preferences. It was found that L2 speakers prefer a native-like accent as they wish to express their identities as competent L2 speakers of English. Similar to Natiladdanon and Thanavisuth's (2014) study, native accents, mainly the US and UK, were preferred over other Asian accents. In addition to students who prefer a native-like accent when speaking English, perspectives from teachers were also explored. Generally, teachers are aware that ELF exists, but they expressed confusion over how its linguistic features, such as writing, would be evaluated (Shetabi \& Rattanaphumma, 2017). This leads to disregarding the existing English varieties (i.e., Singaporean English, Chinese English).

Previous studies of attitude on ELF in Thailand have been based largely on learners from schools and universities. A survey of attitudes toward pronunciation models in English as a lingua franca by Phusit and Suksiripakonchai (2018) found that students have highly positive attitudes towards American/British pronunciation models. Students also believe that maintaining their Thai English pronunciation model was not important. Ploywattanawong and Trakulkasemsuk (2014) conducted a study where the attitudes of Thai graduates were explored in terms of the acceptability and understandability of ASEAN ELF. Around fifty Thai graduate students of engineering, science, and technology participated. Concerning the different grammatical features of ASEAN ELF, the result revealed a neutral judgment for grammatical features for acceptability. The study presented a possible conclusion that although grammatical features of ASEAN ELF may not yet be fully accepted, they do not block understanding of the message in communication. Such studies are in the same line with most previous studies where the attitudes are from students studying at the university were explored (Boonsuk, Ambele, \& Buddharat, 2018; Boonsuk \& Ambele, 2021; Ploywattanawong \& Trakulkasemsuk, 2014; Phusit \& Suksiripakonchai, 2018; Snodin \& Young, 2015; Natiladdanon \& Thanavisuth, 2014).

Recently, a shift in attitude toward ELF from university students was reported. Boonsuk and Ambele (2021) explored how Southern Thai university students view ELF. Around 250 students participated in the questionnaires, and 15 were interviewed. It was found that students are generally proud of their Thai accent. The results suggested that non-native English varieties should not be considered problematic for use. Moreover, such varieties are essential for intercultural communication. The insights suggest that Thai learners may have a more positive attitude towards the use of ELF. 
Different from the academic context, Prakainaurat and Kangkun (2018) investigated language attitudes towards Thai working adults towards native and non-native English varieties at the workplace. A verbal guise test (VGT) and semistructured interview were used as an instrument. Around 80 participants aged between 25-35 participated in the VGT, and 10 participants took part in an interview. These participants came from the field of business, service, and hospitality. The results revealed that most participants tend to view native-varieties (American and British) as more favorable than their non-native counterparts (Filipino, Singaporean, and Thai) regarding social status and competence, attractiveness, and linguistic quality.

As gaps in the literature exist, the present study aims to explore the attitudes on ELF from a broader range of participants in a virtual community and consider their attitude based on "move-in" country of preference.

\section{Methodology}

An instrument used in this quantitative study was a questionnaire adapted from Bartolo (2018) and was distributed online in the Facebook group "โยกย้าย มาส่ายสะโพกโยกย้าย" (Let's move it move it). One hundred ninety respondents participated and consented to take part in the study. There were two sections in the survey. The first section is related to background information such as age, experience abroad, and the country they would like to move to (see Table 1).

TABLE 1

BACKGROUND INFORMATION OF THE PARTICIPANTS

\begin{tabular}{ll} 
& BACKGROUND INFORMATION OF THE PARTICIPANTS \\
\hline \multirow{2}{*}{ Age } & 15 and below $(n=22)$ \\
& $16-20(n=47)$ \\
& $21-25(n=48)$ \\
& $26-30(n=44)$ \\
& 31 and above $(n=29)$ \\
\hline \multirow{2}{*}{ Experience abroad } & Yes $(n=142)$ \\
& No $(n=48)$ \\
\hline \multirow{2}{*}{ Country of preference } & Inner circle $(n=105)$ \\
& Outer circle $(n=3)$ \\
& Expanding circle $(n=53)$ \\
Any circle $(n=29)$ \\
\end{tabular}

In the second section of the questionnaire, eight questions relating to attitudes using English for communicative purposes, learning, and English varieties. All of the items have a translated Thai version next to the English statements to ensure the comprehensibility of statements. The last item was consent for agreement to allow the responses for research purposes.

Respondents were asked to rate their level of agreement on a four-point Likert scale ranging from strongly disagree (1) to strongly agree (4). Samples of the questions are 1) I need to learn English to communicate with both native and non-native speakers of English, and 6) Any linguistic use that does not conform to Standard English is incorrect.

The survey data were analyzed descriptively. The mean scores were interpreted accordingly. The mean score of 1.00 - 1.74 mean Strongly disagree, 1.75 - 2.50 as Disagree, 2.51 - 3.24 mean Agree, and 3.25 - 4.00 as Strongly agree.

\section{FINDINGS AND DisCUSSION}

Table 2 shows the strongly favorable attitudes of Thais toward the following aspects: the focus on intelligibility (Item 2; $M=3.77, S D=0.54$ ); the use of English to communicate with both native and non-native speakers of English (Item 1; $M=3.76, S D=0.54$ ); learning materials for a multicultural environment (Item $7 ; M=3.51, S D=0.64$ ), exposure to varieties of English (Item 6; $M=3.39, S D=0.79$ ). However, despite their favorable attitude, the preferred variety of English to study is British or American standard variety $(M=3.19, S D=0.86)$. 
TABLE 2

ATTITUDES OF THAIS TOWARD ELF

\begin{tabular}{|c|c|c|c|}
\hline Item & $M$ & SD & Interpretation \\
\hline 1. I need to learn English to communicate with both native and non-native speakers of English. & 3.76 & 0.56 & Strongly agree \\
\hline 2. In learning English, the focus on intelligibility (e.g., understanding each other) is crucial. & 3.77 & 0.54 & Strongly agree \\
\hline 3. Any linguistic use that does not conform to Standard English is incorrect. & 2.38 & 1.02 & Disagree \\
\hline 4. I should be taught by teachers of English who should have a standard native-speaker accent. & 2.97 & 0.91 & Agree \\
\hline $\begin{array}{l}\text { 5. The variety of English to be used when I learn English should be Standard British/American } \\
\text { English. }\end{array}$ & 3.19 & 0.86 & Strongly agree \\
\hline $\begin{array}{l}\text { 6. I should be exposed, in learning situations, to varieties of English (Indian English, Chinese } \\
\text { English, Singapore English, African English, etc.) other than Standard British/American English. }\end{array}$ & 3.39 & 0.79 & Strongly agree \\
\hline $\begin{array}{l}\text { 7. Learning materials should include cultural aspects/topics other than Standard British or } \\
\text { American. }\end{array}$ & 3.51 & 0.64 & Strongly agree \\
\hline $\begin{array}{l}\text { 8. In learning English, developing students' proficiency in Standard British/American grammar } \\
\text { forms is crucial. }\end{array}$ & 2.98 & 0.86 & Agree \\
\hline
\end{tabular}

Some respondents have talked about the importance of intelligibility instead of language accuracy (see Excerpts 1 and 2). One even suggested that doing a short-term course in India (Outer circle) or Cambodia (Expanding circle) can be beneficial (see Excerpt 3 ).

Excerpt 1

“ไม่มีเจ้าของภาษาที่ไหนภาษาไหนจะคิดมากเรื่องไวยากรณ์และวิธีการใช้ค่ะ

เพราะใช้ภาษาเป็นอุปกรณ์การสื่อสารและถ้าคุยกันรู้เรื่องก็พอแล้ว มีแค่พวกอาจารย์ พวกจู้จี้จุกจิก และคนขื้อวดเท่านั้นแหละค่ะที่จะชอบทักผิด..." No native speakers would care so much about grammar and its usage since language is a tool for communication. It's enough if it's understood. Only teachers and a fastidious person like to correct others.

Excerpt 2

"แกรมม่า ฟรั่งไม่แคร์ เขาเข้าใจ เราครับ เขารู้ว่าเราจะพูดอะไร เขามีมารยาท" Caucasians don't care about the grammar; they can understand what we want to convey. They have manners.

Excerpt 3

"...แนะนำให้ลองไปเรียนภาษาระยะสั้นๆดูก่อนที่ตปทค่ะ มีหลายประเทศเลยนะคะ ลองอินเดียไม่ก็กัมพูชาดูก็ได้ค่ะ ค่าครองชีพเท่าๆบ้านเราตอนนี้หนูมาเรียนภาษาอังกฤษที่กัมพูชา คล่องขึ้นมากกว่าแต่ก่อนเยอะเลยค่ะ..." I'd like to suggest you to study the [English] language abroad in a short course first. Many countries are available. Try India or Cambodia. The cost of living is similar to our country. I study English in Cambodia, and my English is a lot better than before.

However, other individual views on the importance of grammar were also shared due to work and workplace demands (see Excerpts 4, 5, and 6). For example, to be able to work abroad, one must possess linguistic competence.

Excerpt 4

“เห็นด้วยมากๆค่ะ จากประสบการณ์ตัวเองที่ไม่ได้เรียนสายอินเตอร์มา ตอนนี้ทำงานออฟฟิศอยู่ที่เนเธอร์แลนด์ว่า แกรมม่านั้นสำคัญ..." I totally agree with you. From my experience, I did not study at an international program. Now, I work at an office in the Netherlands and grammar is so important.

Excerpt 5

“แกรมม่าสำคัญมากๆ ค่ะ ยิ่งพอมาทำงานในองค์ต่างชาติใหญ่ นี่ยิ่งต้องพูด ต้องเขียนให้ถูกแกรมม่า ถ้าแกรมม่าไม่ได้ อาจจะพูดผิด เขียนผิด สื่อความหมายผิด

อาจจะมีผลต่อความก้าวหน้าในการทำงานองค์ต่างประเทศในอนาคตค่ะ เรามั่นใจพูดได้

กับพูดแล้วฝรั่งเข้าใจโดยฝรั่งไม่ต้องเดา มันต่างกันค่ะ" Grammar is so important. Once I come to work at a large foreign organization, I must speak more and write correctly. If the grammar is incorrect in speaking or writing, the message will also be wrong. This could affect the advancement towards my future career in working for a foreign organization abroad. I'm confident that I could speak and speak, and Caucasians could understand by not guessing two different things.

Excerpt 6

"เราอยู่อเมริกาค่ะ ขึ้นอยู่กับตัวงานคุณด้วย อย่างงานเรา detail เรื่องการเขียนและภาษามาก การเขียนใช้ grammar ผิดๆสื่อถึงการทำงานที่ส่ะเพร่า ถ้างานคุณไม่ซีเรียสเรื่องนี้ก็ว่าไปอย่าง 
แต่มันก็บ่งบอกหลายอย่างในตัวคุณได้ว่าคุณพยายามที่จะเรียนรู้ขนาดไหน หรือว่าคุณเพิกเฉยไปวันๆ" I live in the US, and it depends on your job as well. For me, language detail and writing are so important. Using ungrammatical sentences reflects a lack of detail at work. If you're not serious, then it's fine, but it could reflect so many things about how much you try to learn, or you're just let it pass by.

Table 3 displays the differences in attitudes based on their country of preference. The Any Circle group had the highest mean scores on four statements: learn English to communicate with any speakers of English (Item 1), prefer to learn standard English varieties (Item 5), exposure to varieties of English (Item 6), and importance of developing standard English grammar competency. On the other hand, they had the strongest objection to item 3 - Any linguistic use that does not conform to Standard English is incorrect. The Inner Circle group had the highest mean score on item 4 - teachers' preference with a native accent. Everyone in the Outer Circle group agreed that intelligibility is the most important (Item 2). The Expanding Circle group believed that learning materials should include other varieties of English (Item 7).

The findings in the present study seemed to offer different perspectives away from previous studies conducted with university students (Boonsuk \& Ambele, 2021; Boonsuk, Ambele, \& Buddharat, 2018; Kanoksilapatham, 2013; Natiladdanon \& Thanavisuth, 2014; Phusit \& Suksiripakonchai, 2018; Ploywattanawong \& Trakulkasemsuk, 2014; Snodin \& Young, 2015). We believed that the findings are different because of the context of the study and the inclusion of a more diverse population from various age groups. We are wrong with our assumption that those who have chosen to "move-in" in an Inner circle country are more inclined to native speakerism as Thais in the current study have shown favorable attitudes toward ELF.

The respondents in the Facebook group appear to agree that intelligibility is of crucial importance strongly. English is seen as a tool to communicate among the group members, and perhaps their Thai English accent and grammatical accuracy may be less prioritized. Excerpts 1 and 2 support the aspect of intelligibility when using English. The way they talk about grammatical accuracy implies a negative feeling towards those who try to correct their grammar by comparing Thais to the welcoming of native speakers in terms of acceptability and judgment in using English. The finding in our study is in contrast to that of Phusit and Suksiripakonchai (2018), where most learners were found to likely imitate American and British accents and that linguistic accommodation was less emphasized (Phusit \& Suksiripakonchai, 2018). One of the reasons may be related to participants and context. The participants involved in Phusit and Suksiripakonchai's (2018) study were all English majors students at the undergraduate levels. These English major students may hold English in a native norm more prestigious and favorable due to less exposure to other Englishes. Moreover, they may have to stick to the native norm and standard (American and British) since they need to use this knowledge to enter an English major program at a university. American and British English is still used as a gatekeeper for university entrance in Thailand. Similar to Sung (2016), who concluded that ELF users negatively perceive non-native accents. Similar findings were found by Jindapitak and Teo (2012), where students are not aware of other varieties of English and that learners are linguistically prejudiced towards other nonnative accents. Again, these previous studies are mainly conducted in the mainstream educational context at the tertiary levels. Moreover, English major students were often the participants in the previous studies on ELF (Phusit \& Suksiripakonchai, 2018; Jindapitak $\&$ Teo, 2012). 
TABLE 3

DIFFERENCES OF ATTITUDES BASED ON THEIR COUNTRY OF PREFERENCE

\begin{tabular}{|c|c|c|c|c|}
\hline Item & $\begin{array}{l}\text { Inner Circle } \\
\quad M, \mathrm{SD}\end{array}$ & $\begin{array}{l}\text { Outer Circle } \\
\quad M, \mathrm{SD}\end{array}$ & $\begin{array}{l}\text { Expanding } \\
\text { Circle } \\
M, \mathrm{SD}\end{array}$ & $\begin{array}{l}\text { Any Circle } \\
\qquad, \mathrm{SD}\end{array}$ \\
\hline $\begin{array}{l}\text { 1. I need to learn English to communicate with both native and } \\
\text { non-native speakers of English. }\end{array}$ & $\begin{array}{l}3.68,0.63 \\
\text { Strongly agree }\end{array}$ & $\begin{array}{l}3.67,0.58 \\
\text { Strongly agree }\end{array}$ & $\begin{array}{l}3.85,0.50 \\
\text { Strongly agree }\end{array}$ & $\begin{array}{l}3.93,0.26 \\
\text { Strongly agree }\end{array}$ \\
\hline $\begin{array}{l}\text { 2. In learning English, the focus on intelligibility (e.g., } \\
\text { understanding each other) is crucial. }\end{array}$ & $\begin{array}{l}3.71,0.62 \\
\text { Strongly agree }\end{array}$ & $\begin{array}{l}4.00,0.00 \\
\text { Strongly agree }\end{array}$ & $\begin{array}{l}3.85,0.41 \\
\text { Strongly agree }\end{array}$ & $\begin{array}{l}3.83,0.47 \\
\text { Strongly agree }\end{array}$ \\
\hline $\begin{array}{l}\text { 3. Any linguistic use that does not conform to Standard English } \\
\text { is incorrect. * }\end{array}$ & $\begin{array}{l}2.43,0.98 \\
\text { Disagree }\end{array}$ & $\begin{array}{l}2.33,1.53 \\
\text { Disagree }\end{array}$ & $\begin{array}{l}2.36,1.06 \\
\text { Disagree }\end{array}$ & $\begin{array}{l}2.24,1.06 \\
\text { Disagree }\end{array}$ \\
\hline $\begin{array}{l}\text { 4. I should be taught by teachers of English who should have a } \\
\text { standard native-speaker accent. }\end{array}$ & $\begin{array}{l}3.03,0.88 \\
\text { Agree }\end{array}$ & $\begin{array}{l}3.00,1.00 \\
\text { Agree }\end{array}$ & $\begin{array}{l}2.91,0.95 \\
\text { Agree }\end{array}$ & $\begin{array}{l}2.90 .0 .98 \\
\text { Agree }\end{array}$ \\
\hline $\begin{array}{l}\text { 5. The variety of English to be used when I learn English should } \\
\text { be Standard British/American English. }\end{array}$ & $\begin{array}{l}3.11,0.92 \\
\text { Agree }\end{array}$ & $\begin{array}{l}3.00,1.00 \\
\text { Agree }\end{array}$ & $\begin{array}{l}3.25,0.76 \\
\text { Strongly agree }\end{array}$ & $\begin{array}{l}3.38,0.78 \\
\text { Strongly agree }\end{array}$ \\
\hline $\begin{array}{l}\text { 6. I should be exposed, in learning situations, to varieties of } \\
\text { English (Indian English, Chinese English, Singapore English, } \\
\text { African English, etc.) other than Standard British/American } \\
\text { English. }\end{array}$ & $\begin{array}{l}3.30,0.87 \\
\text { Strongly agree }\end{array}$ & $\begin{array}{l}3.33,0.58 \\
\text { Strongly agree }\end{array}$ & $\begin{array}{l}3.49,0.67 \\
\text { Strongly agree }\end{array}$ & $\begin{array}{l}3.55,0.69 \\
\text { Strongly agree }\end{array}$ \\
\hline $\begin{array}{l}\text { 7. Learning materials should include cultural aspects/topics } \\
\text { other than Standard British or American. }\end{array}$ & $\begin{array}{l}3.49,0.65 \\
\text { Strongly agree }\end{array}$ & $\begin{array}{l}3.33,1.15 \\
\text { Strongly agree }\end{array}$ & $\begin{array}{l}3.64,0.48 \\
\text { Strongly agree }\end{array}$ & $\begin{array}{l}3.36,0.78 \\
\text { Strongly agree }\end{array}$ \\
\hline $\begin{array}{l}\text { 8. In learning English, developing students' proficiency in } \\
\text { Standard British/American grammar forms is crucial. }\end{array}$ & $\begin{array}{l}2.98,0.90 \\
\text { Agree }\end{array}$ & $\begin{array}{l}\text { 3.00, } 1.00 \\
\text { Agree }\end{array}$ & $\begin{array}{l}2.92,0.78 \\
\text { Agree }\end{array}$ & $\begin{array}{l}\text { 3.07, } 0.84 \\
\text { Agree }\end{array}$ \\
\hline
\end{tabular}

*Item 3 is stated negatively.

The English language is used for communication for both native and non-native speakers. These are supported by items 3, 6, and 7. Item 3 reflects respondents' attitude towards using English to communicate by disagreeing with the need to conform to the standard English norms in its linguistic use. This may imply that they do not expect to strictly use accurate linguistic features (American/British English) in oral communication between native and non-native speakers. Thus, learning other standards such as Singaporean English or Indian English may be one of the alternative pathways that they prefer. Perhaps these varieties of English are spoken in countries they would like to visit. This may be why item 6 receives such a strongly agreed statement that learners should be exposed to English varieties other than the American and British standards. Standards such as Chinese English and African English could be integrated into the classroom to explore. As language comes with culture, item 7 supports previous attitudes of items 3 and 6 by suggesting that other cultural aspects and topics other than the British and American should be included in the learning materials. The attitude from the members of the Expanding circle has the highest agreement on item 7. This suggests that not only do learners have positive attitudes towards ELF but also the cultures and local traditions that intertwine in the English language as well.

Respondents from the Outer circle group strongly agreed with item 2 that intelligibility is of crucial importance. This is perhaps because English is explicitly learned for the sake of communication purposes. Excerpt 3 demonstrates this by recommending other group members to go to countries in the outer and expanding circles to learn English. Cost of living was one of the factors to be considered in the excerpt. This implies that those who want to learn English may prefer to go to countries with less opportunity to speak Thai, and countries with English as an official language may not always be the first destination to consider anymore when learning English. This is interesting because it was found that English language learners in Thailand have a negative attitude towards varieties of English in the ASEAN countries compared to American and British English (Natiladdanon, 2014). In addition, the result may reflect that most learners are calling for more opportunities to use English in their surroundings. As long as English can be used for intelligible communication, Expanding circle could also be one choice.

Item 7 was strongly agreed upon by members from the Expanding circle group. Other cultural aspects and topics other than the standard American and British should be included when learning English. Content related to other cultures and traditions of different expanding circle countries may be learned through English. ELF is a choice made to foster language learning, and these two interactions of CLIL and ELF have received very little attention in the literature(Hüttner, 2017). Another reason is perhaps because British companies publish most educational materials available in the market. Members who seek to learn English may not have an apparent reference to comparing varieties of English standards when studying in an English class. Moreover, teachers in the Thai education system may not be fully aware of the ELF paradigm, making them feel uncomfortable selecting materials from the ELF perspectives. It was reported that teachers expressed confusion over ELF and that it is problematic when evaluating linguistic aspects such as writing from the ELF perspectives. As a result, most teachers took the traditional approach towards the so- 
called standard American and British English (Shetabi \& Rattanaphumma, 2017). Based on the findings, we call for more research on developing materials that could reflect other cultural topics and aspects other than standard American and British English and approaches that could be integrated into the English language classroom.

Members from Any circle group were found to have the most positive attitude (see items 1, 3, 6, and 8). In addition, they were the group that strongly disagreed with conforming to the linguistic use of standard British and American English. This implies that they are quite detached from the native-speaker norms in terms of the linguistic aspects as they appear to be more open and accepting when mistakes are made by people who do not conform to the standard rules. However, item 5 seems to be contradictory towards positive attitudes to ELF. When learning English, members from the Any circle group become reattached to the standard native British and American English. The findings are similar to that of Jindapitak and Teo (2013), where learners tend to prefer native-accent models. However, they were willing to learn and understand more about non-native English.

\section{CONCLUSION}

The paper aims to investigate the attitude of ELF among different Thais and whether there are differences based on their country of preference from a sample of participants from a Facebook group called "โยกย้าย มาส่ายสะโพกโยกย้าย" (Let's move it move it). The present study provided insights into a specific group of Thais toward English as a lingua franca by categorizing them based on Kachruvian three concentric circles - Inner, Outer, and Expanding as well as Any circle - a combination of two or more circles. Generally, Thais' attitudes are broadly favorable toward intelligibility, language accuracy, and exposure to varieties of English, among others. Even those who prefer to "move-in" in Inner circle countries tend to have a positive attitude towards ELF. However, the strong attachment of the Expanding and Any circle groups toward learning standard American or British English strongly persists. Future studies may delve into the factors influencing the attitudes of a more diverse sample population from mainstream society.

\section{REFERENCES}

[1] Al-Saggaf, Y. (2017). Information sharing on Facebook by alone, single and lonely female users. SEARCH The Journal of the South East Asia Research Centre for Communication and Humanities, 9(1), 97-116.

[2] Bamgbose, A. (1998). Torn between the norms: Innovations in world Englishes. World Englishes, 17(1), 1-14.

[3] Boonsuk, Y., \& Ambele, E. A. (2021). Towards integrating lingua franca in Thai EFL: Insights from Thai tertiary learners. International Journal of Instruction, 14(3), 17-38.

[4] Boonsuk, Y., Ambele, E. A., \& Buddharat, C. (2018). Reconsidering the practical aspects of ELF in Thai E.L.T. classroom. Journal of Human Sciences, 19(1), 93-121.

[5] Coyle, D., P. Hood, and D. Marsh. (2010). Content and Language Integrated Learning. Cambridge: Cambridge University Press.

[6] De Bartolo, A. M. (2018). Learners' awareness and attitude towards ELF. A pilot study in an Italian University context. Lingue e Linguaggi, 26, 157-172.

[7] Dhaha, I. S. Y. A., \& Igale, A. B. (2014). Motives as predictors of Facebook addiction: Empirical evidence from Somalia. SEARCH: The Journal of the South East Asia Research Centre for Communication and Humanities, 6(2), 1-22.

[8] Ellis, R. (1994). The Study of Second Language Acquisition. Shanghai: Shanghai Foreign Language Education Press.

[9] Holliday, A. (2006). The struggle to teach English as an international language. Oxford, England: Oxford University Press.

[10] Hüttner, J. (2017). ELF and content and language integrated learning. London: The Routledge Handbook of English as a Lingua Franca (pp. 481-493).

[11] Jenkins, J. (2006). Points of view and blind spots: ELF and SLA. International Journal of Applied Linguistics, 16(2), $137-162$.

[12] Jenkins, J. (2009). English as a lingua franca: Interpretations and attitudes. World Englishes, 28(2), 200-207.

[13] Jindapitak, N., \& Teo, A. (2012). Thai tertiary English majors' attitudes towards and awareness of world Englishes. Journal of Studies in the English Language, 7. 74-115.

[14] Jindapitak, N., \& Teo, A. (2013). Accent Priority in a Thai University Context: A Common Sense Revisited. English Language Teaching, 6(9), 193-201.

[15] Kachru, B. B. (Ed.). (1992). The other tongue: English across cultures. Illinois: University of Illinois Press.

[16] Kanoksilapatham, B. (2013). Thai university students' voices heard: Aspired pronunciation model. Journal of Studies in the English Language, 8. 124-135

[17] Krisvianti, S., \& Triastuti, E. (2020). Facebook group types and posts: Indonesian women free themselves from domestic violence. SEARCH The Journal of the South East Asia Research Centre for Communication and Humanities, 12(3), 1-17.

[18] Natiladdanon, K. (2014). Attitudes, Awareness, and Comprehensibility of ASEAN English Accents. Human Behavior, Development and Society, 9(1), 16-30.

[19] Phusit, N., \& Suksiripakonchai, W. (2018). A study of Thai university students' attitudes towards pronunciation models in English as a lingua franca. International Journal of Social Science and Humanity, 8(1), 20-24.

[20] Ploywattanawong, P., \& Trakulkasemsuk, W. (2014). Attitudes of Thai graduates toward English as a Lingua Franca of ASEAN. Asian Englishes, 16(2), 141-156.

[21] Prakaianurat, P., \& Kangkun, P. (2018). Language attitudes of Thai working adults toward native and non-native English varieties. Manusya: Journal of Humanities, 21(2), 92-111.

[22] Rheingold, H. (1993). The virtual community. Retrieved from https://www.rheingold.com/vc/book/ (accessed 15/4/2021). 
[23] Sangnok, P., \& Jaturapitakkul, N. (2019). Perceptions of Thai Undergraduate Students toward the Asian English Accents on Listening Comprehension. REFLections, 26(2), 24-50.

[24] Seidlhofer, B. (2011). Understanding English as a Lingua Franca. London, England: Oxford University Press

[25] Shetabi, Y., \& Rattanaphumma, R. (2017). A Study of Teachers' Awareness of ELF and an Analysis of ELF Features of Primary School Students' Writings at an International School in Bangkok. The New English Teacher, 11(2), 118-118.

[26] Snodin, N. S., \& Young, T. J. (2015). 'Native-speaker' varieties of English: Thai perceptions and attitudes. Asian Englishes, $17(3), 248-260$.

[27] Sung, C. C. M. (2016). Does accent matter? Investigating the relationship between accent and identity in English as a lingua franca communication. System, 60, 55-65.

[28] Waters, A. (2007). Native-speakerism in ELT: Plus ça change...?. System, 35(3), 281-292.

[29] Zhang, Y., \& Du, X. (2018). Chinese University Students' and Teachers' Perceptions of and Attitudes towards ELF Journal of Pan-Pacific Association of Applied Linguistics, 22(2), 1-25.

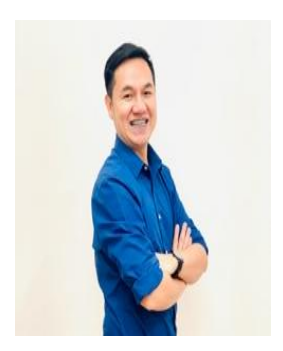

Jeffrey Dawala Wilang hails from Dilong, Tubo, Abra. He currently lectures at the School of Foreign Languages, Institute of Social Technology, Suranaree University of Technology, Nakhon Ratchasima, Thailand. Dr. Wilang earned his bachelor's degree in Political Science from the University of the Cordilleras (UC) in the Philippines, his master's degree in Teaching English as an International Language from the Faculty of Liberal Arts, Prince of Songkla University (PSU), Hat Yai Campus in Thailand, and his Ph.D. in Applied Linguistics from the School of Liberal Arts, King Mongkut's University of Technology Thonburi (KMUTT), Thailand. His research interests are psycholinguistics and English as a lingua franca.

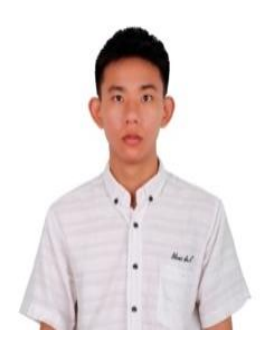

Piyathat Siripol is currently a Master student in Applied Linguistics (ELT) at King Mongkut's University of Technology Thonburi. He received a bachelor's degree in English (1st class honors) from Khon Kaen University, Thailand. His research interests include EFL teaching methodologies and second language writing. 